\title{
Evaluation on Samaranch’s Innovations for Olympic Development
}

\author{
Jiahao Hu \\ English Department, Wuhan Institute of Physical Education, Wuhan, China. \\ Email: huwaston@hotmail.com \\ Received September $1^{\text {st }}$, 2011; revised October $10^{\text {th }}$, 2011; accepted October $15^{\text {th }}$, 2011.
}

\begin{abstract}
Under certain political and economic background Samaranch implemented a series of innovations for Olympic development. His reform focuses on Olympic commercialization, sport professionalization and women sport, which brings about both active and passive results. The essay demonstrates Samaranch's great contributions towards world Olympic movement. On the other hand it points out the negative results of Samaranch's reformation with the intention to warn the people in the future.
\end{abstract}

Keywords: Samaranch, Innovation, Olympic Development, Evaluation

\section{Introduction}

Juan Antonio Samaranch, the most successful chairman of the International Olympic Committee (IOC) left us for ever. During his tenure, the Olympic movement has experienced a series of economic and political crises. With his super-wisdom, he firmly innovated and enriched the meaning of Olympic movement. The essay focuses on the historical development of his innovations, reflecting his outstanding contributions and influences on the modern Olympics in post-Samaranch era.

\section{Background of Samaranch's Innovations}

After Samaranch was elected as IOC President in 1980, IOC faced the plight for survival and development. From political point of view, capitalism and socialism, two major political forces at that time, existed in a cold war. U.S.A. boycotted Moscow Olympics together with other 65 capitalist countries, including his motherland, Spain. Spanish athletes even did not play national flag at the opening ceremony. Moscow Olympics endured a disastrous boycott, putting the largest investment with the smallest reward. Coincidentally, Los Angeles Olympics were also boycotted by socialist countries led by the Soviet Union. Socialist camp even sought to persuade UNESCO to take its place to exercise all the functions of IOC.IOC was on the verge of disintegration. From economic poit of view, IOC could hardly protect itself, let alone assist member states to promote universal Olympic movement.At that time IOC owned working capital of less than \$20 million and fixed assets worth of $\$ 2,000,000$. In addition, the construction of the Montreal Olympic Stadium caused huge debts up to $\$ 10$ billion. The example made other cities reluctant to host the Olympics. In 1980 and in 1984 only the United States contested to bid for winter Olympics and summer Olympics. After Los Angeles won the contest, the government was not willing to provide any financial assistance because local taxpayers outcried against wasting the valuable capital for the Olympics. In such a poor economic background, the prospect of modern Olympics was colorless and bleak. Some people even suspected that IOC only owned a dead end ( Zhou A-bao, 2006).

\section{Samaranch's Innovation}

In front of the political and economical difficulties, Samar- anch accepted the challenge. He had two roads to choose. One road is to maintain the status doing nothing and waiting to die. The other road is to innovate for prosperity. With great encouragement Samaranch chose the latter and actively seeked for effective solutions to the above problems.

\section{Innovation on Relationship Improvement between IOC and Political Organizations}

At birth, Coubertin, the founder of the Olympic movement, made the principle to separate sports from politics. Samaranch had worked for a long time in political field and formed a strong passion towards politics. The past political career told him that politics accompanied the whole Olympic movement all the time. What interested sport field also interested politicians. Those who engaged in sports could not escape political influence. His special understanding about politics helped him to take a quite different view from Coubertin. In order to improve the relations between IOC and political organizations for the flourishment of modern Olympics, Samaranch actively strived for the support from all national governments, based on the IOC independence. First of all, he made face- to- face dialogues with the political leaders from different countries, deepening the mutual understanding and cooperation. The wide communications helped him to solve the conflict still in the embryonic stage. Before taking any actions, political leaders at least made the first consultation with IOC to find a solution satisfactory to both sides. U.S. President Jimmy Carter implemented the political boycott against Moscow Olympics while socialist countries carried out the passive resistance against Los Angeles Olympics. Samaranch tried every means to meditate between the two sides. On a visit to the United States, he persuaded Reagan, President of the United States, to invite the general secretary of the Soviet Union to participate the opening ceremony of Los Angeles Olympics. The plan didn't succeed, but such socialist country as China, Romania and Yugoslavia actively participated in the game. Across the world, 140 delegations and 6797 athletes attended, creating the modern Olympic record with the largest number of participants (Xiong Douying, 2010).

Additionally, Samaranch established friendly relationship with the United Nations (UN) to improve IOC international image. For many years, UN attached great importance to IOC which benefited quite a lot from kofi Annan's supports. With Samaranch's efforts, UN approved the Olympic truce idea to 
call for every opposite party to stop conflict during the Olympics. Unanimously UN 180 members agreed on the Olympic truce proposal to build a better world through sports activities and the Olympic spirit of peace. Having cooperated harmoniousely with UN, IOC gradually went out of crisis and enhanced the vitality step by step. The Olympic spirit continuously carried forward across the whole world (Ren Hai, 2007).

\section{Innovation on the Olympic Commercialization}

World Olympics had takn government offer for its main financial source all the time. But this pattern evolved into folk Olympics in the United States. Los Angeles Olympics was hard to collect enough money. Organizing committee creatively got funds through agreement with sponsors from big enterprises. They sold the television rights by open tender and earned more than $\$ 2$ billion of income, turning the game a successful commercial model without government subsidies. For the first time all funding was raised by the game itself. Therefore, Samaranch granted the gold medal to the committee of Los Angeles Olympics, indicating his commercial innovation. He boldly abandoned coubertin's non-commercial principle. Under his leadership, financial resources sub-committee and market development sub-committee successively established and began to operate. When Olympic Games was held in Calgary in Canada, the American broadcasting company bought the exclusive right to broadcast the programme in America with more than \$3 billion. Samaranch earned the first bucket of gold for the Olympic movement. But he wasn't eager for quick success and instant benefit. Immediately he realized that Olympic spirit would lose if IOC soly relied on the exchange of television right. The Olympics should be distinguished from the general commercial sports contest. Therefore, he intentionally added special remarks to the agreement that TV media could not interfer IOC from making any decisions. The remarks thus carried on Coubertin's ideal of Olympic independence. Although some private TV stations offered much more money, Samaranch refused to sign agreement with them because he strictly sticked to the priciple that Olympic TV signal must be broadcasted free of charge for everyone to enjoy. In his eye, everyone could afford to watch Olympic programme as long as he loved the Olympics. No economic barriers could prevent him from pursuing Olympic movement. Moreover, IOC clearly rejected any sponsorship from tobacco manufacturers (Wang Ying, 2007). In Olympic venues and the Olympic village any form of advertisement was not allowed because the Olympic movement aimed at promoting health. Although the Olympic broadcast revenue was considerable, IOC still needed more revenue to ensure its absolute economic independence. So Samaranch began to implement the Olympic partner programme for highest-level partners. Samaranch granted intellectual property rights and marketing rights to the Olympic partner. Samsung Electronics Company from South Korea joined the partner programme. Relying on the Olympic propagation, Samsung soon entered into the world top 500 enterprises. Reciprocally, the partner programme changed the fate of the modern Olympic movement in a revolutionary way. It was the key move for IOC to become prosperous. The partner programme guaranteed full independence and autonomy of IOC.

\section{Innovation on Olympic Professionalization}

Coubertin stood against the Olympic professionalization.The Olympic charter specified clearly that amateur athlete engaged in sports out of hobby or for entertainment expecting no mate- rial benefits. No professional athletes, besides fencing, could join in any other Olympics. Obviously, this regulation drew all professional players out. As a result international sports formed two coexisting camps, the amateur party and the professional party like the world cup, or NBA. There is no doubt that NBA level is far above amateur basketball team. Due to professional limitation, such basketball king or football emperor as pele, Franz beckenbauer had no chance to play in the Olympics. The audience could hardly please their eyes. Gradually they lost their interests in the Olympics. Audience was the root for the existence of the Olympics. So Samaranch made the final choice opposite to coubertin. He advocated to revise the Olympic charter by clearly stipulating that athlete was qualified to take part in the Olympics as long as he complied with both the regulations of IOC and that of the international sports federations. The revision allowed the contestant to participate in the Olympics if he didn't use his name or image to make advertisements. Under such premise, the Olympics opened the door to the best players in the world, neglecting his professional identity. Samaranch also supported to reach agreement successively with FIFA, horse alliance, etc. allowing professional athletes to take part in the Olympics. In 1991 new eligibility criteria was listed on the Olympic charter that athletes should be sent by Olympic committee in his own country. This showed that the boundaries between amateur athletes and professional ones were cancelled. In 1992 NBA basketball star appeared in Barcelona Olympic Games. This was the first time for professional athletes to enter into the Olympic hall, adding more enjoyment to the audience. TV media attracted more audience, too. Without too many limitations, Olympics absorbed more athletes and consolidated maximum of them to push forward sports movement.

\section{Innovation on Women's Olympic Participation}

In history, the Olympics was the symbol of male's strength, allowing only man to participate. Watching the Olympic Games was man's prerogative. Coubertin once openly showed his discrimination against women by saying that: "as for allowing women to take part in the Olympic Games, I still firmly oppose. More and more female athletes are allowed to compete, and this is against my will.” In Samaranch's mind, sport belonged to all human mankind, including men and women. Everyone was equal to watch or attend the Olympics. Due to the characteristics of sport game, some projects were even more suitable for women. With such point of view Samaranch absorbed female members into the IOC. Finland female athlete, Pierre Raman, and Venezuela female athletes, Fonseca, were elected respectively as IOC members. Proposed by Samaranch, woman special working committee was set up in 1995, over which Anita, former female Olympic champion, presided. Since then, IOC in each nation and each sport federation kept certain seats for female officials. In spite of busy work Samaranch especially attended women sports conference held in Paris, on which he called on national governments to take measures to encourage women to come close to sports. Samaranch formed the tradition to attach great importance to woman sport. Beijing Olympics is a good example. Among 302 projects, female project amounted to 127 and the mixed project took up 10. Compared with Athens Olympics, Beijing Olympics increased 2 female projects (Li Xiaolan, 2005).

\section{Conclusions}

Samaranch inherited an old IOC, but he left us a totally new 
one. Innovatively he accepted professional sports and flexiblely cooperated with political authorities of UN. He aptly sold television rights to realize Olympic commercialization in a stable way. All the incomes were used to promote women sports. Due to his innovation, the Olympic movement revived and opened a new chapter(Zhao Dexun, 2007)

\section{Positive Aspects of Samaranch's Innovations}

The times helped Samaranch to make great achievements and post- Samaranch era proved his innovation. In 2008, 203 countries and regions participated Beijing Olympics, which made the highest historical record. Although various factors caused the breakthrough, it is undeniable that the Olympic prosperity came after Samaranch's innovation. Today many non-European countries have made successful bid for the Olympics and more and more developing countries are rather active in Olympic movement. The Olympic movement is developing with much more balance in all continents.

Shortly after taking office Samaranch devoted to Olympic professionalism. Professional player's involvement turned the Olympics into the most popular sporting events. Fueled by commerciaization, the Olympics has become a great business with biggest social, economic and political influence. Every government, major public media and each well-known big enterprise are quite enthusiastic in Olympics. The Olympic rings have become a global mark with the highest recognition. In the past not many countries competed to host. Today cities rack their brains for successful bidding. The ownership of Olympics has become a worldwide hottest topic.

Olympic doctrine is to combine sports and education together. From the birth of Olympics, coubertin defined its educational function. The mutual confluence of competative sports and education aims to cultivate people. Olympic education is an important content in the international Olympic sports promotion and development. Coubertin was eager to build the Olympic museum to cultivate people's virtue. This dream turned true through samaranch's effort. With strong economic strength through commercialization, IOC built the Olympic museum in Switzerland so that the Olympic spirit could be passed from generation to generation. So far, over a million tourists have visited museum. It has truly carried forward the Olympic spirit. Samaranch is worth the name as the educator and communicator of the Olympic spirit.

\section{Negative Aspects of Samaranch's Innovations}

Samaranch's innovations made outstanding and glamorous achievement. Under his leadership, IOC moved constantly towards glory. But he is not a perfect man, neither is his innovation. His experience is a mirror of our future practice, from which we should draw some lessons to avoid repeating similar mistakes.

Olympics expresses people's hope to pursue the ideal to be true, to be good and to be beautiful. Through competitive sports they long for world peace and mutual understanding between various nations. By sport they yearn for unity and sports ethics. Instinctively any commercial behavior must pursue maximum of economic benefits. When sports criterion and economic benefit lose balance, merchants will not hesitate a moment to prefer the latter, which will inevitably produce great impact on Olympism. Following Samaranch's commercial reform, doping flooded in sports fields. It not only affected few games and several people, but betrayed the Olympic spirit. Commercialization did harm to the whole Olympic cause. Although
Samaranch were cautious about it and took all possible measures to control the highly commercial Olympics, but he could not reverse the trend. Atlanta Olympics had strong commercial taste and was out of control. Seeking for maximum of benefit, Coca-Cola Company made full use of Olympics to advertise their products. The image of the company went far beyond the light of Olympics itself. Atlanta Olympics became a real "Coca-Cola Olympics", whose evolution was far away from the Olympic pursuit to be true, to be good and to be beautiful. When broadcasting the programmes, business company considered the demands of market for higher coverage. To meet the needs of TV broadcasting, sponsors could change the match time according to audience's interest convenience for high profits. Broadcasters even cancelled some programmes because audiences didn't appreciate them. During Beijing Olympic Games, swimming final match and most gymnastic games were held in the morning of Beijing time because it was evening of American time, the golden period for American fans to watch programmes.

Although Olympics do not grant any material rewards to athletes, the great honors can bring them stunning prestige. Popular atheletes can gain great advertising revenue. In order to win the best Olympic achievements, athletes are willing to take every gross means. Before kreegan, the women figure skater, competed for an Olympic candidate, she was suddenly attacked by a man, patellar and quadriceps severely injured. The next day she was not able to attend the contest. Harding, her rival, easily ranked first and won the qualification. Later the police investigated that kreegan's attack related to Harding's ex-husband. It was he who spent money hiring thugs to hurt kreegan.

Olympic professionalization also widens the gap between developed region and developing region. It is well known that American professional athletes in basketball, hockey, football and baseball have reached the top level of the world. Other countries can't hold a candle to them. American athletic program also goes ahead. They have produced the main Olympic golds without many rivals. Professionalization benefits American sports quite a lot. Meanwhile, the level of the other countries are far behind that of the United States, which prevents the competitive projects from developing in a benign way. Professionalisation is a double-edged sword enhancing the attractiveness of sports and producing imbalance crisis in sport.

In recent years IOC has strongly supported female project, issuing new regulation that every newly-added project must include female part. As a result, Olympic projects increase greatly. Since Samaranch took office, the scale of Olympics has expanded for the sake of Olympic movement. Competitors and excessive number of participating nations have increased dramatically. 172 countries and regions were in Barcelona Olympics in 1992. 12 years later the number achieved a record 202 in Athens (Hu Jiahao, 2011). The quantity of coaches, referees, journalists, security staff and service personnel was extremely impressive. Such a big scale is certainly a heavy burden to any host city. Even Los Angeles Olympics or Sydney Olympics encountered such confusion as the idle sports venues and hard-to- return investment. Host city inevitably faced economical risk at different levels. These questions really need serious considerations for the following generations after Samaranch.

\section{References}

Hu, J.-H. (2011). 2008 Olympic Games and the improvement of Beijing competitiveness. Journal of Nanjing Institute of Physical Educa- 
tion, 1, 80-84.

Li, X.-L., \& Zhang, H.-Y. (2005). Feminist trend and the changing of the Olympic women's sports development. Journal of Chengdu Institute of Physical Education, 31, 23-25.

Ren, H. (2007). Olympic reform and IOC transformation. Journal of Sports Culture, 12, 39-41

Wang, Y. (2007). Discussions on the survival and development of the modern Olympic movement. Journal of Capital Institute of Physical
Education, 195, 36-38.

Xiong, D.-Y. (2010). Thoughts about establishing Olympics. Sports Science, 1, 4-9

Zhou, A.-B. (2006). Autobiography of Samaranch. Beijing: Huaxia Press.

Zhao, D.-X. (2007). Management mode shift of IOC. Guangzhou: South China Normal University. 